\title{
A Patient with Typhoid Hepatitis
}

\author{
M Vitanata Arfijanto*, Isty Rindryastuti** \\ *Division of Tropical Infectious Disease, Department of Internal Medicine, Faculty of Medicine \\ Universitas Airlangga, Dr.Soetomo General Hospital, Surabaya \\ ${ }^{* *}$ Department of Internal Medicine, Faculty of Medicine \\ Universitas Airlangga, Dr.Soetomo General Hospital, Surabaya
}

\section{Corresponding author:}

M. Vitanata Arfijanto. Division of Tropical Infectious Disease, Department of Internal Medicine, Dr. Soetomo General Hospital. Jl. Mayjen Prof. Dr. Moestopo 6-8 Surabaya Indonesia. Phone: +62-31-5501617, 5501615, 5501199; facsimile: +62-31-5018434,5012239.Email:drvitanata@gmail.com.

\begin{abstract}
Typhoid hepatitis is typhoid fever accompanied by symptoms of jaundice, hepatomegaly and abnormal liver function tests. The incidence varies between $0.4-26 \%$ of typhoid fever patients. We report a case of a 34-yearold male, presented with fever, epistaxis, gastrointestinal symptoms, thrombocytopenia and elevated AST/ALT, thus the patient was first diagnosed as dengue hemorrhagic fever grade II. On day $9^{\text {th }}$ the signs and symptoms were persisted, Ig M and Ig G Dengue was negative. Then we evaluated the virus marker for hepatitis and blood culture. The results were negative for HBsAg, anti HCV and Ig M anti HAV, but Salmonella typhi detected on blood culture. The patient was treated with ceftriaxone $1000 \mathrm{mg}$ bid iv and get better then discharged from hospital.
\end{abstract}

Keywords: Typhoid hepatitis, salmonella hepatitis, typhoid fever, demam enterik, Salmonella typhi

\section{ABSTRAK}

Hepatitis tifosa adalah demam tifoid yang disertai gejala-gejala ikterus, hepatomegaly dan kelainan tes fungsi hati. Insidennya bervariasi antara 0,4-26\% dari pasien demam tifoid. Kami sajikan kasus seorang laki-laki, usia 34 tahun, datang dengan demam, epistaksis, gejala gastrointestinal, trombositopenia dan peningkatan AST/ ALT, sehingga pada awalnya pasien didiagnosis dengan demam berdarah dengue stadium II. Pada hari ke-9, keluhan dan gejala menetap, dengan Ig M dan Ig M Dengue negatif. Kami periksa penanda virus hepatitis dan kultur darah. HBsAg, anti HCV dan Ig M anti HAV negatif, tetapi didapatkan pertumbuhan kuman Salmonella typhi pada kultur darah. Pasien diterapi dengan seftriakson iv tiap 12 jam dan sembuh serta dipulangkan.

Kata kunci: epatitis tifosa, salmonella hepatitis, demam tifoid, enteric fever, Salmonella typhi

\section{INTRODUCTION}

Typhoid fever is a common infectious disease in developing countries, associated with high morbidity and mortality, thus becoming a global health problem. In 2000, it was estimated that more than 2.16 million cases of typhoid fever worldwide, resulted in 216,000 deaths, and more than $90 \%$ of these morbidity and mortality occurred in Asia ${ }^{1,2}$.
In Indonesia, the incidence of typhoid fever averages 900,000 cases per year with more than 20,000 deaths. The largest population is aged 3-19 years which constitutes $91 \%$ of cases of typhoid fever and positive blood culture for typhoid fever is 1026 per 100,000 per year ${ }^{3}$. In Indonesia, there is no data on the incidence of typhoid hepatitis.

The clinical features of typhoid fever vary widely 
with increasing atypical symptoms. Typhoid hepatitis is typhoid fever accompanied by symptoms of jaundice, hepatomegaly and abnormal liver function tests. ${ }^{4}$ It is one of the atypical clinical features of typhoid fever and should be considered in patients with fever and features of liver involvement, especially in endemic areas, because it can mimic other diseases that occur in this area, such as acute viral hepatitis, amoebic hepatitis or malaria. ${ }^{5}$ We report a case of a patient with typhoid hepatitis.

\section{CASE ILLUSTRATION}

A 34-year-old male, Surabaya, Javanese, single, private employee, from Surabaya, admitted to infectious ward of Dr. Soetomo General Hospital with chief complaint of fever. The patient had fever since 5 days before admission. The temperature was immediately high and went normal if taking paracetamol. The patient also complains of nausea, vomiting, and diarrhea. The diarrhea was about 5 times per day, the amount of \pm 1 tablespoon each, yellow color, no blood and mucus. The stomach feels bloated, but no abdominal pain. No changed on urinate. The patient had nosebleed once, but no gums bleeding and red spots on body parts. The history of flooding, traveling to eastern Indonesia, having dengue fever in the home or work environment is denied. Patients often eat at the street food stall.

From physical examination found that the general condition was weak, GCS 456, blood pressure 130/80, pulse rate $90 \mathrm{x} /$ minute, regular and adequate pulse, respiratory rate $20 \mathrm{x} /$ minute, axillary temperature $39.8^{\circ} \mathrm{C}$. On head and neck examination, there were no anemia, jaundice, cyanosis, conjunctival suffusion, typhoid tongue, enlarged lymph nodes and increased jugular venous pressure. On examination of the heart, there was no abnormality, there was no lung abnormality. Abdominal examination shows distension, increased bowel sounds and meteorism. The liver and spleen were not palpable, there was no metallic sound, shifting dullness. In the superior and inferior extremities, there is no ptekie, edema.

Laboratory examination on addimision day were haemoglobin (hb) $11.2 \mathrm{~g} / \mathrm{dL}$, hematocrit (hct) $33 \%$, leukocytes $4,400 / \mu \mathrm{L}$, platelets $77,000 / \mu \mathrm{L}$, granulocytes $78.5 \%$, partial thromboplastin time (PTT) 11.7 seconds/ control 10.9 seconds, activated-partial thromboplastin time (aPTT) 25.2sec/control 26secs, random blood glucose (RBG) $96 \mathrm{mg} / \mathrm{dL}$, aspartate transaminase (AST) 454U/L, alanine transaminase (ALT) 222U/L, albumin 3,4g/dL, blood urea nitrogen (BUN) $16 \mathrm{mg} / \mathrm{dL}$, creatinine serum $(\mathrm{CrS}) 1.25 \mathrm{mg} / \mathrm{dL}$, sodium $127 \mathrm{mmol} / \mathrm{L}$, potassium $3,2 \mathrm{mmol} / \mathrm{L}$, chloride $94 \mathrm{mmol} / \mathrm{L}$, calcium $8.3 \mathrm{mg} / \mathrm{dL}$, widal slide: typhi $\mathrm{O}(-)$, typhi $\mathrm{H} 1 / 320$, paratyphi A (-), paratyphi B (-). Chest X-ray was normal.

Based on anamnesis, physical, laboratory and radiology examination, we diagnosed the patient as dengue hemorrhagic fever (DHF) grade II + Acute Kidney Injury (AKI) dd Acute on Chronic Kidney Disease $(A C K D)+$ elevated transaminase pro evaluation + Hypovolemic hypotonic hyponatremia + Hypokalemia. Planning for this patient management were high-calorie high protein diet $2000 \mathrm{kcal} /$ day with extra fruit, vegetable, broth, Asering Ringer infusion $1500 \mathrm{~mL} / 24 \mathrm{~h}$, ranitidine $50 \mathrm{mg} / 24 \mathrm{~h}$ iv, paracetamol $500 \mathrm{mg}+\mathrm{n}$-acethyl sistein $200 \mathrm{mg} 1 \mathrm{tab} / 8 \mathrm{~h}$ prn, KSR $600 \mathrm{mg} /$ day, serial CBC, serum electrolyte, AST \& ALT, BUN \&CrS, Ig M \& Ig G Anti Dengue, HBsAg, Anti HCV, IgM anti HAV.

On $4^{\text {th }}$ day of admission, the patient still had fever (day $9^{\text {th }}$ ), diarrhea, nausea, vomiting and bloating, but there are no epistaxis and gum bleeding. The patient has no history of drugs user, free sex, tattoo, typhoid fever before. From physical examination we found that general condition was still weak, GCS 456, blood pressure 120/70, pulse rate 80x/ minute, regular and adequate, respiratory rate $20 \mathrm{x} /$ minute, axillary temperature $38.8^{\circ} \mathrm{C}$, the palpebral conjungtiva looked jaundice, the abdomen was still distended, increased bowel sounds and meteorism. The laboratory finding: $\mathrm{hb} 11,1 \mathrm{~g} / \mathrm{dL}$, hematocrit $31.6 \%$, leukocytes $4400 / \mu \mathrm{L}$, platelets $43,300 / \mu \mathrm{L}$, granulocytes $71.9 \%$, AST $656 \mathrm{U} / \mathrm{L}$, ALT $288 \mathrm{U} / \mathrm{L}$, BUN $13 \mathrm{mg} / \mathrm{dL}, \mathrm{CrS} 0.62 \mathrm{mg} / \mathrm{dL}$, sodium $129 \mathrm{mmol} / \mathrm{L}$, potassium $3,5 \mathrm{mmol} / \mathrm{L}$, chloride $91 \mathrm{mmol} / \mathrm{L}, \mathrm{Ig} \mathrm{M} \&$ Ig $\mathrm{G}$ anti Dengue, $\mathrm{HbsAg}$, Anti HCV, Ig M anti HAV were all negative. Based on that data we dignosed the patient as suspected typhoid hepatitis + Acute Kidney Injury (AKI) improved + Euvolumic hyponatremia + Corrected hypokalemia, with diagnostic and therapeutic planning: CBC \&peripheral blood smear, direct bilirubin, total bilirubin, AST \& ALT, stool analysist, Ig M Salmonella, stool and blood culture, plain abdominal radiograph, HIV 3 methods serology test, abdominal ultrasonography, bed rest, diet high calories high protein $2000 \mathrm{kcal} /$ day low fiber, $\mathrm{NaCl}$ $0.9 \% 1500 \mathrm{~mL} / 24 \mathrm{~h}$ iv, ceftriaxone $1 \mathrm{~g} / 12 \mathrm{~h}$ iv, ranitidine $50 \mathrm{mg} / 24 \mathrm{~h}$ iv, paracetamol $500 \mathrm{mg}+\mathrm{n}$-acethyl sistein 200mg $1 \mathrm{tab} / 8 \mathrm{~h}$ prn.

On day $6^{\text {th }}$ the signs and symptoms are getting better and the laboratory results are $\mathrm{Hb} 11.7 \mathrm{~g} / \mathrm{dL}$, leukocytes 
$5600 / \mu \mathrm{L}$, platelets $56,700 / \mu \mathrm{L}$, AST $353 \mathrm{U} / \mathrm{L}$, ALT 269U/L, bilirubin direct $1.11 \mathrm{mg} / \mathrm{dL}$, bilirubin total $1.73 \mathrm{mg} / \mathrm{dL}, \mathrm{LDH} 765 \mathrm{U} / \mathrm{L}$, ratio ALT/LDH $0.35, \mathrm{Ig}$ M Salmonella positive, HIV 3 methods serology test negative. We diagnosed the patient as typhoid hepatitis + Acute Kidney Injury + Euvolumic hyponatremia + post hypokalemia.All theraphies were continued.

On day $8^{\text {th }}$ the patient was better, with laboratory results were sodium $129 \mathrm{mmol} / \mathrm{L}$, potassium $3,5 \mathrm{mmol} / \mathrm{L}$, chloride $91 \mathrm{mmol} / \mathrm{L}$, blood culture: Salmonella typhisensitive toaztreonam, amoxicillinclavulanic acid, ampicillin, ampicillin-sulbactam, pepiracillintazobactam, ceftazidime, cefotaxime, cefoperazone-sulbactam, cotrimoxasol, tetracyclines, chloramphenicol, fosfomycin, imipenem, meropenem; resistant to amikacin, tobramycin, gentamicin, cefazolin. The diagnosis and treatment were persist. The patient was getting better clinically and laboratory and discharged after 10 days of hospitalization.

\section{DISCUSSION}

Typhoid fever is caused by $S$ typhi or $S$ paratyphi, spread through the ingestion infectious doses of bacteria from contaminated water or food which is affected by poor sanitation. ${ }^{6}$ After passing the gastric, the bacteria reach the small intestine and invade the intestinal epithelium through $\mathrm{M}$ cells contained in Peyer's plaque which are then phagocytes by macrophages, then through the mesenteric lymph ducts and thoracic ducts enter the systemic blood circulation (bacteremia I) and reach the reticuloendothelial cells in the liver, spleen and bone marrow. S.typhi or S.paratyphi replicates in phagocytes, which are then recognized by the human immune system, thereby stimulating the release of proinflammatory cytokines, antibodies and the release of endotoxins. Bacteria and endotoxins then enter the gallbladder and systemic blood circulation again (bacteremia II) which causes symptoms of typhoid fever. ${ }^{7}$

The clinical symptoms of typhoid fever are not specific, include fever $(100 \%)$, headache (80\%), chills (35-45\%), cough (30\%), sweating (20-25\%), myalgia $(20 \%)$, malaise $(10 \%)$, arthralgia (2-4\%). Common gastrointestinal symptoms include anorexia 55\%, abdominal pain (30-40\%), nausea (18-24\%), vomiting (18\%), diarrhea (22-28\%), constipation (13-16\%). On clinical examination, can be found typhoid tongue (51-56\%), relative epistaxis and bradycardia $(<50 \%)$, rose spots $(30 \%)$, abdominal tenderness $(4-5 \%)$, hepatosplenomegaly $(3-5 \%))^{7,10}$
The definitive diagnosis of typhoid fever requires isolation of S.typhi or S.paratyphi from blood, bone marrow, other sterile sites, feces or gastrointestinal secretions. Blood culture sensitivity is only $40-80 \%$, probably due to antibiotic use and only small amounts of S.typhi are present in the blood (usually $<15$ organisms $/ \mathrm{mL}$ ). Bone marrow culture has a sensitivity of $55-90 \%$, and unlike blood cultures, the results can remain positive after 5 days of antibiotic use ${ }^{7}$.

This patient had 10 days of fever, nausea, vomiting, diarrhea, relative bradycardia, hepatomegaly with positive S.typhi blood culture results so that it was confirmed typhoid fever.

Hematogenous spreading of organisms or toxins from salmonella can cause systemic involvement that affects all major organs ${ }^{8}$. Liver involvement in typhoid fever was first reported by William Osler in $1899^{8,9}$. The pathogenesis of typhoid hepatitis is not completely clear, it is thought to be multifactorial, including direct hepatic damage by invading bacteria, endotoxin, or inflammatory processes and or secondary damage due to host immune mechanisms. ${ }^{5,11}$

In typhoid hepatitis, the frequent clinical features are hepatomegaly and an increase in transaminases that occur in $23-60 \%$ of typhoid fever patients ${ }^{9,11}$. Diagnosis of typhoid hepatitis is a probable case or confirmed case of typhoid fever with meets 3 or more criterias: (a) hepatomegaly, (b) jaundice, (c) biochemical abnormalities, or (d) liver histopathology 8,12

This patient was confirmed typhoid fever, as well as jaundice, hepatomegaly, increased bilirubin, AST and ALT that met the diagnostic criteria for typhoid hepatitis.

The clinical symptoms of typhoid hepatitis are difficult to distinguish from other causes of fever and jaundice, especially in the first 5 days of the disease course. In most areas, acute viral hepatitis and non-infectious causes of hepatitis (eg, druginduced liver injury, toxic or alcoholic hepatitis), are the main differential diagnosis of typhoid hepatitis. In developing countries, typhoid hepatitis is similar to other infectious diseases such as leptospirosis, malaria, amoebic liver abscess, dengue fever. ${ }^{5}$

The patient was initially diagnosed with DHF grade II, but the fever persisted on $9^{\text {th }}$ days, with intestinal complaints (nausea, vomiting, diarrhea, bloating), relative bradycardia, jaundice, positive Salmonella IgM, positive $S$ typhi blood culture, elevated serum transaminase, increased bilirubin, abdominal ultrasound: non-specific hepatomegaly, negative dengue Ig $\mathrm{M}$, 
Table 1. Recommended Antibiotic Treatment for Typhoid Fever, $6,7,14$.

\begin{tabular}{|c|c|c|c|c|c|c|}
\hline \multirow[b]{2}{*}{ Susceptibility } & \multicolumn{3}{|c|}{ Optimal Treatment } & \multicolumn{3}{|c|}{ Alternative Effective Treatment } \\
\hline & Antibiotics & $\begin{array}{l}\text { Dose } \\
\mathrm{mg} / \mathrm{kg}\end{array}$ & $\begin{array}{l}\text { Course } \\
\text { Day }\end{array}$ & Antibiotics & $\begin{array}{l}\text { Dose } \\
\mathrm{mg} / \mathrm{kg}\end{array}$ & $\begin{array}{l}\text { Course } \\
\text { Day }\end{array}$ \\
\hline \multicolumn{7}{|c|}{ Uncomplicated disease } \\
\hline \multirow[t]{3}{*}{ Sensitive } & Fluoroquinolone & 15 & $5-7$ & Chloramphenicol & $50-75$ & $14-21$ \\
\hline & & & & Amoxycillin & $75-100$ & 14 \\
\hline & & & & TMP-SMX & $8-40$ & 14 \\
\hline \multirow[t]{2}{*}{ MDR } & Fluoroquinolone & 15 & $7-14$ & Azithromycin & $8-10$ & 7 \\
\hline & Cefixime & $15-20$ & $7-14$ & Cefixime & $15-20$ & $7-14$ \\
\hline Quinolone & Azithromycin & $8-10$ & 7 & Cefixime & 20 & $7-14$ \\
\hline Resistance & Ceftriaxone & 75 & $10-14$ & & & \\
\hline \multicolumn{7}{|l|}{ Severe disease } \\
\hline \multirow[t]{3}{*}{ Sensitive } & Ciprofloxacin orOfloxacin & 15 & $10-14$ & Chloramphenicol & 100 & $14-21$ \\
\hline & & & & Amoxycillin & 100 & 14 \\
\hline & & & & TMP-SMX & $8-40$ & 14 \\
\hline \multirow[t]{2}{*}{ MDR } & Fluoroquinolone & 15 & $10-14$ & Ceftriaxone & 75 & $10-14$ \\
\hline & Cefixime & $15-20$ & $10-14$ & Cefotaxime & 80 & $10-14$ \\
\hline \multirow{3}{*}{$\begin{array}{l}\text { Quinolone } \\
\text { resistance }\end{array}$} & Ceftriaxone & 75 & $10-14$ & Fluoroquinolone & 20 & $7-14$ \\
\hline & Cefotaxime & 80 & $10-14$ & & & \\
\hline & Azithromycin & $8-10$ & $10-14$ & & & \\
\hline
\end{tabular}

MDR: multi drugs resistant; TMP-SMX: trimethoprim-sulfametoxazole

negative anti-HAV IgM, negative $\mathrm{HBsAg}$, negative HBC negative, 3 methods HIV serology negative, so then diagnosed as typhoid hepatitis.

Severe typhoid fever (occurs 10-15\%) is influenced by host factors (immunosuppression, therapy that reduces stomach acid, previous exposure, vaccination) and germ virulence, the choice of antibiotic therapy. Complications can include gastrointestinal bleeding (10-20\%), intestinal perforation (1-3\%), neurological manifestations (2-40\%) including meningitis, Guillain-Barré syndrome, neuritis and neuropsychiatric symptoms. ${ }^{7}$

The general principles of management of typhoid hepatitis are the same as typhoid fever, which are rapid diagnosis and proper administration of antibiotics, adequate rest, hydration and correction of electrolyte imbalance, administration of anti-pyretics if needed, adequate diet (soft diet, easy to digest unless there is abdominal distension or ileus), hand washing and limiting contact with susceptible individuals during acute phase infection, follow-up and monitoring of complications and recurrences ${ }^{6}$. The choice of antibiotics is based on local resistance patterns and antibiotic sensitivity. ${ }^{13}$

The patient had no symptoms and signs of severe typhoid fever and received bed rest therapy, highcalorie diet high protein $1800 \mathrm{kcal} /$ day low fiber, $0.9 \%$ 14 tpm $\mathrm{NaCl}$ infusion, $2 \mathrm{x} 1 \mathrm{~g}$ iv ceftriaxone injection for 7 days, ranitidine injection $1 \times 50 \mathrm{mg}$ iv . Antibiotic therapy was continued with cefixime $2 \times 100 \mathrm{mg}$ po.

The prognosis for typhoid hepatitis is generally good because it responds well to antibiotics. However, the mortality can reach $20 \%$ in conditions of malnutrition, anemia and/or late receiving appropriate and adequate therapy. Diagnosis and therapy with appropriate antimicrobial agents are very important to reduce mortality. ${ }^{15}$
The patient improved clinically and laboratory after receiving antibiotic therapy and was discharged after 10 days of treatment.

Typhous hepatitis is very difficult to distinguish from acute viral hepatitis, amoebic hepatitis, malaria, dengue hemorrhagic fever or leptospira. Typhous hepatitis must always be considered in patients with fever and impaired hepatic function, especially in endemic areas, because prompt diagnosis and appropriate antibiotic therapy will reduce mortality.

\section{REFERENCES}

1. Ochiai RL, Acosta CJ, Danovaro-Holliday MC, Baiqing D, Bhattacharya SK, AgtiniMD, et al. A study of typhoid fever in five Asian countries: disease burden and implications for controls. Bulletin of the World Health Organization 2008;86: 260-8.

2. Crump JA, Mintz ED, 2010. Global trens in typhoid ad paratyphoid fever. Clin Infect Dis 2010;50: 241-6.

3. World Health Organization Department of Vaccines and Biologicals. Background document: The diagnosis, treatment and prevention of typhoid fever. Geneva: WHO, 2003.p.1-38.

4. Kemenkes RI, 2006. Pedomanpengendaliandemamtifoid. Jakarta: KementrianKesehatanRepublik Indonesia

5. Pramoolsinsap C, Viranuvatti V. Salmonella hepatitis. J Gastroenterol Hepatol 1998;13:745-50.

6. Bhutta ZA. Current concepts in the diagnosis and treatment of typhoid fever. BMJ 2006;333:78-82.

7. Pegues DA, Miller SI. Salmonellosis. In: Kasper DL, Fauci AS, Hauser SL, Longo DL, Jameson JL, Loscalzo J, eds. Harrison's Principles of Internal Medicine. $19^{\text {th }}$ edition. New York: McGraw Hill Education 2015.p.1049-55.

8. Madi D, Achappa B, Ramapuram JT, Chowta N, Laxman M, Mahalingam S. Atypical presentation of typhoid fever. Asian J Med Sci 2014;5:140-2.

9. Karoli R, Fatima J, Chandra A, Singh G. Salmonella hepatitis: an uncommon complications of a common disease. Journal of Family Medicine and Primary Care 2012;1:160-2. 
10. Khurshid A, Rashid J. Clinical presentation of typhoid fever. Annals 2006;12;556-9.

11. Husain EH. Fulminant hepatitis in typhoid fever. J Infect Public Health 2011;4:154-6.

12. Khosla SN. Typhoid hepatitis. Postgrad Med J 1990;66:923925.

13. Ratnayake EC, Shivanthan C, Wijesiriwardena BC. Cholestatic hepatitis in a patient with typhoid fever - a case report. Ann Clin Microbiol Antimicrob 2011;35:1-3.

14. World Health Organization, 2011. Guidelines for the management of typhoid fever. Geneva: WHO 2011.p.1-39.

15. Albayrak A, Gunbey SS, Aktas F. Cholestatic hepatitis due to Salmonella typhi. Clin Pract 2011;1:e13:22-3. 